\title{
«I Can't Get the Practical Hours»: Care, Course Choice and Role Conflict Among Student-Mothers in Higher Education in Scotland
}

\author{
«No puedo completar las horas prácticas»: cuidado, elección de cursos y \\ conflicto de roles para madres-estudiantes en el sistema de estudios \\ superiores en Escocia
}

Thiago Bogossian ${ }^{1}$

\begin{abstract}
Mothers who study at a higher education level face many challenges that traditional students do not. They have less time to study and must negotiate their different commitments and responsibilities, which includes taking care of their children. This article reports on qualitative research conducted with a group of mothers that study at a prestigious university in Scotland to understand their experiences of belonging to the space of the institution and their perceived learning challenges. Four interviews and one focus group were organised, voice recorded and their transcripts were thematically analysed and engaged with the research questions. It has found that they experience limited support from the institution which is compensated by family and peer support, changes in courses to accommodate their needs and varied levels of emotional distress. Experiences of student-mothers remain largely invisible in scholarly research and higher education policy. Thus, this paper contributes to a bridging of this gap by bringing the voices of student-mothers to the foreground..
\end{abstract}

Keywords

Student parents, mothers, care, higher education, widening participation.

\section{Resumen}

Madres dentro del sistema de estudios superiores se enfrentan a un gran número de retos que los estudiantes tradicionales no. Tienen menos tiempo para estudiar y deben negociar entre diferentes compromisos y responsabilidades, incluyendo el cuidado de sus hijos. Este artículo reporta los resultados de una investigación cualitativa realizada con un pequeño grupo de madres-estudiantes en una prestigiosa universidad de Escocia, con el fin de entender sus experiencias de pertenencia al espacio dentro de la institución y sus retos durante el proceso de aprendizaje. Cuatro entrevistas y un grupo focal fueron realizados, las grabaciones y transcripciones fueron analizadas temáticamente y vinculadas a las preguntas de investigación. Los resultados demostraron que reciben apoyo limitado por parte de la institución, el cual es compensado por el apoyo de su familia y compañeros; al igual que cambios en sus materias para acomodarse a sus necesidades y niveles variados de aflicción emocional. Las experiencias de las madres-estudiantes se mantiene altamente invisible en investigación escolar y políticas de estudios superiores. Es así que este documento contribuye a reducir la brecha al traer las voces de las madres-estudiantes a un primer plano.

\section{Palabras clave}

Padres estudiantes, madres, cuidado, estudios superiores, ampliar participación.

\section{Cómo citar/Citation}

Bogossian, Thiago (2021). "I Can’t Get the Practical Hours": Care, Course Choice and Role Conflict Among Student-Mothers in Higher Education in Scotland. Revista de Sociología de la Educación-RASE, 14 (2), 157-170. http://dx.doi.org/10.7203/RASE.14.2.16896. 


\section{Introduction}

«Because I have to do everything at home, from cooking to cleaning, to taking care of children, to attending school's [clubs]... things like that. It meant that I could only study when they were asleep [chuckles]. It wasn't very easy because I was really tired at that time». (Irene, part-time PG international student).

Mothers who attend higher education (HE) institutions face many challenges that traditional students do not. They must negotiate constraints of time and space between their education and other tasks they must do on a regular basis. Taking care of their children, which might include dropping them off and/or picking them up at kindergarten or school, preparing meals, cleaning up the house and working part or full-time might be part of their busy everyday schedules (DeVault, 1991). Different than most students at UK HE, who are young, single and have no caring responsibilities, mothers report distinct experiences that connect to their own personal stories and barriers they must overcome. As the excerpt above from Irene, one of the participants in this study, demonstrates, the overlap with work and family obligations is one of the challenges they must face when they assume simultaneously the role of mothers and HE learners.

This article details part of a study conducted with seven student mothers at a prestigious university in Scotland. It examines participants' perceived support and learning difficulties and their course choices in the intersection of a mother-student identity. It draws from four in-depth interviews and one focus group with mothers, who have not received yet enough attention from HE institutions and educational policies (Brooks, 2012a). This paper is important as Widening Participation policies do not tackle specifically students with caregiving responsibilities and literature has not explored enough the experiences of HE student-mothers.

This paper is structured as it follows. First, I review literature on Widening Participation in the UK, discuss the concept of 'non-traditional' HE student and engage with the scholarly debate of the experiences of student-mothers at universities in the country. As there is no body of literature on student-mothers experiences in Scotland in particular, I looked for wider debates in the UK and Europe. I then move on to present the methodology and methods used in this study. Further, I analyse three key themes that emerged from the transcripts of the focus group and interviews conducted in this study. I discuss that participants experience limited support from their university, had to adapt their course choice and career because of their caring responsibilities, and that they suffered varied levels of emotional distress due to demands and role conflicts. I conclude the paper by outlining my contribution to the scholarly debate, by highlighting the importance of bringing voices of underrepresented groups to the front and by suggesting changes in academic culture to include these and other non-traditional students so they can thrive their full potential.

\section{Mother-students and their invisibility in Widening Participation (WP)}

Students from working class families, ethnic minorities, mature students and students with disabilities are usually underrepresented in HE in the United Kingdom (Marshall, 2016), especially in prestigious institutions (Moreau, 2016). Non-traditional learners experience a lack of academic and interpersonal validation with stressful situations because of their multiple responsibilities, low sense of community affiliation and 
few opportunities to participate in social life on campus (Witkowsky et al., 2016). In other words, material reasons interact with symbolic ones, where perceptions of accessibility also play a role in blocking these groups to access, remain and feel they belong in HE.

Within this context, the UK and Scottish governments have a policy to expand enrolment of underrepresented groups in HE. Widening Participation (WP), also called Widening Access, is the most important policy in ensuring that minorities and other disadvantaged groups access HE. However, these groups receive the controversial label of 'non-traditional' students, which demonstrates that there is still a normalising discourse of the university learner, who is traditionally considered to be white, male, middle class, young, able-bodied and with no domestic or caring responsibilities (Leathwood and O'Connell, 2003; Moreau, 2016). Academic knowledge has been constructed as the preserve of a white masculine body, a view that excludes or marginalises women, particularly mothers, who were traditionally relegated to the private domestic space (Moreau, 2016).

Access to HE in the UK still relies heavily on previous academic performance, which makes 'a significant contribution to the continuing inequity in the way in which different socioeconomic groups are represented in HE' (Moreton, 2016: 92). Moreau (2016) indicates that neoliberal reforms from the 1980s and 1990s bolstered the lack of space for care in higher educational institutions, reinforcing masculine hegemonies of productivity, geographical mobility and short-term availability. In other words,

\section{"Colleges [...] still largely operate on outmoded systems designed for younger, geographically stable, full-time students. They are not well structured to meet the needs of workers and parents. Addres- sing this concern entails reconsidering how course schedules are designed, the extent to which credits are transferable, the distribution of financial aid, and even the nature of course work». (Sweet} and Moen, 2007: 245).

Still, WP is widely recognised as the most important policy in the UK to address inequalities in higher education. WP in Britain includes mature learners as one of the underrepresented social groups in HE institutions. However, even though many mature students are caregivers, it is not necessarily true for all of them (Brooks, 2012a; Alsop et al., 2008). The absence of the concept of care in WP also indicates there is no specific focus on parental responsibilities on higher educational policy. There are no official numbers on student carers in HE in Scotland (Carers Trust Scotland, 2020) or in the UK (Alsop et al., 2008) because universities are not required to collect this data (National Union of Students, 2009), meaning there is no authoritative data on how many students have children. In European countries, however, circa $10 \%$ of HE students are parents, mostly mothers (Haugas, 2018), and there is no reason to expect a huge difference between this and the Scottish counterparts. In any case, despite the lack of precise numbers, it has been argued that any expectation of increase of mature students must recognise care as part of their experience in HE policy (Alsop et al., 2008).

In comparison with other European countries, the UK falls short in support for students who are parents. Brooks (2012b) found that Denmark, for instance, pays a universal grant to all students and grants a maternity and paternity compensated leave if they become parents during their studies. The author indicates that in Denmark the institutions appeared to be more sensitive to potential diversity within the student body than their UK counterparts' (Brooks 2012b: 436). This lack of sensitivity in the UK results 
in many student-mothers reporting struggle, related to financial, time, health and emotional difficulties in their journey through higher education (Alsop et al., 2008; Andrade and Matias, 2017; Moreau and Kerner, 2015; Marandet and Wainwright, 2010).

Brooks (2012b) also reported that staff in the UK problematised student-parents, devaluing their ability to carry on with their studies due to parenthood while Danish respondents declared that some of the students with caring responsibilities were models of time management to other learners. Mothers from other studies demonstrated they acknowledge and appreciate academic staff recognising their contribution or allocating resources to their specific needs (Alsop et al., 2008; Deutsch and Schmertz, 2011). On the other hand, Andrade and Matias (2017) found that even though there was lack of educational and work institutional support for mothers taking master's courses, their family and peer assistance and encouragement was crucial for the completion of their degree.

Findings from literature discussed in this section suggest that the condition of being mother and student in a HE setting usually makes it harder for them to succeed. This paper is therefore important as it contributes understanding of student-mothers to the current body of literature. The results presented in this paper outline how students perceive the lack of care that appears in WP policies in their own institution and how their caring obligations constrain their course and career choices and produce disturbances and poor wellbeing.

\section{Methodology and Methods}

This research was conducted based on an interpretivist epistemological position (Mack, 2010) and on qualitative methodology, where detailed and in-depth information from participants was analysed (Cohen et al., 2018; Creswell, 2012). Initially, my plan was to carry out only focus groups to gather a shared understanding of the experiences of student-mothers in HE. I used the Doodle website to find a common slot between me and at least three participants. The first focus group was successful but after that we struggled to find slots where more than two participants could commit to because they had other obligations, including care. In one instance, one of the student-mothers cancelled her participation in the night before the meeting and another called me to cancel their participation 30 minutes before the slot, leaving just me and another participant. After that, I decided to carry on with in-depth one-to-one interviews, which I do not believe had impacted on the results.

Participants were recruited through Facebook groups and snowball sampling. The inclusion criteria was being a mother and a student at the university in Scotland where the study was conducted. Seven participants were recruited: four took part in one-to-one in-depth interviews and three in one focus group. Sampling revealed an interesting but unplanned diversity: there were part and full-time learners, international and domestic, postgraduate and undergraduate, single-mother and married students. All of them were, however, from Arts, Humanities and Social Sciences degrees. A summary of their demographics is below. 


\section{Table I. Participants Summary}

\begin{tabular}{|c|c|c|c|c|c|c|}
\hline PSEUDONYM & LEVEL & COURSE & CIVIL STATUS & NATIONALITY & MODE & CHILDREN AGE \\
\hline Jane & Undergraduate & Social and Public Policy & Married & Scottish & Full-time & 8 and 13 \\
\hline Eleanor & Postgraduate & Children's Literature and Literacies & Widowed & Indian & Full-time & 9 and 12 \\
\hline Christina & Postgraduate & Photography & Married & Brazilian & Part-time & 2 and 7 \\
\hline Carrie & Undergraduate & Archaeology and Celtic Studies & Married & Scottish & Full-time & 1,12 and 17 \\
\hline Irene & Postgraduate & Children's Literature and Literacies & Married & Greek & Part-time & 2,14 and 17 \\
\hline Holly & Postgraduate & Education & Divorced & Indian & Full-time & 8 \\
\hline Maria & Postgraduate & Education & Married & Australian & Full-time & 1 \\
\hline
\end{tabular}

Interviews and focus group had unstructured outline, with open-ended questions, providing time to participants to reflect and explain their positions. Questions ranged from their perception of safety and accessibility within the institution, their relation to different spaces within campus and their perceived learning challenges. Our meetings were conducted in one of the university's classrooms, and in the university library. The interviews and focus group lasted between 40 and 90 minutes and were audio recorded. After these meetings, the audio files were transcribed into a document processing software. Data was analysed through thematic analysis (Braun and Clarke, 2006; Creswell, 2012) that searched for themes and patterns across the set. Units of meaning were identified from each of the transcriptions individually, then they were coded as a group and then classified into more general and abstract themes, based on the research questions. Three larger themes were identified: juggling studies with other commitments, sense of belonging and support. These were analysed and engaged with the academic debate and reframed into six results that were reported in the master's dissertation of the author. Three of them are discussed in the following sections.

The research was approved by the School of Education Ethics Committee from the University of Glasgow and by the university where I recruited volunteers. All the names in this paper are pseudonyms.

\section{Results and discussion}

In this section, I analyse three key findings from my interaction with the interviewees and the transcriptions in contrast with academic literature on this subject. First, I discuss the marginal place of care at the institution, that does not offer enough guarantees of safety, access and belonging to these mothers. On the other hand, participants reported they create their own networks of support and use their own knowledge and skills to navigate through university life.

Then, I move to analyse their course choices. Along with the traditional debate in Sociology of Education that suggests that career and course choices are not based solely in individual and personal aspirations (Mendick, 2013; Reay et al., 2005; Williams et al., 2008), I argue that these women negotiate their choices according to a set of possibilities and tools available to them, and their caring responsibilities play an important role in constraining these choices.

Finally, I discuss that these mothers report lack of wellbeing and health disturbances due to role conflict (Allen et al., 2000; Andrade and Matias, 2017). They wish to perform well in both of their roles as mothers and as students but sometimes time or resources are not available to them. When this happens, they report frustration, lack of academic validation, isolation and feelings of guilt and misery. I argue that these feelings affect their ability to study and to learn, which happens to a lesser extent with traditional students. 


\title{
4. 1. The Marginal Place of Care
}

The institution has an important role to play so students can feel they belong or are supported. However, non-traditional students are less likely to believe their institutions take actions to prevent discrimination or support their full engagement with the university. According to Witkowsky et al., (2016), these students do not feel their experiences and perspectives are validated by staff and student peers in and out the classroom. Their study also reported discrimination regarding attendance requirements and unequal treatment in the classroom.

Findings from my study hold similarities, but also differences, with the findings from Witkowsky et al., (2016). Maria, a PhD international student, had a great experience with the student financial services staff, who encouraged her to apply for a hardship fund she was unaware of. On the other hand, Carrie, an undergraduate working-class Scottish student, mentioned a horrendous episode where she felt abandoned by the student services support. During her first semester, she had both her childminder and father ill in the hospital at the same time, so she had no childcare and was feeling unwell. She went to see a student support services and they told her that she did not need to worry, because she only needed a D3 to go through the year - which the minimum 'satisfactory' grade to pass at this university. This implies a disposition of low performance from students who are mothers, which mirrors the study from Brooks (2012a).

Eleanor complained about the lack of information on basic services on campus and around the city tailored to international students. She arrived at her student flat with two young children and several suitcases without knowing it was on the fifth floor. She summarises the institutional approach to student-mothers:

\begin{abstract}
«See, when I was applying, the application process actually never differentiated between a mother or a student, so it was the same for all, so I never knew that there are few facilities specifically for mothers. ... I was never even asked about my status, if I am a single parent or a mother or whatever, so it was never differentiated ... for a person like me I would bave appreciated it if they would have asked or they would have acknowledged that' 'ok, maybe I will need some more support when I come here'.» (Eleanor, full-time Postgraduate, single-mother, international student).
\end{abstract}

The institution does not have information on student-parents and therefore can do little to support these people, either on their arrival or during their studies. This finding connects with previous research that mentioned that, despite collecting information on age, gender, nationality and so forth, 'institutions do not generally hold any data on the number of enrolled students with dependent children', making the experience of these students invisible (Marandet and Wainwright, 2010: 789). The authors also suggest that although there has been an expansion of access to HE for underrepresented groups, little has been done to change cultural codes of institutions to suit demands of this new student body.

Nevertheless, lack of support from the institution was compensated by the students own efforts and networks, which is corroborated by findings from O'Shea (2015). According to this author, mature and caregiver students rely on their own resources compared to younger students. Holly, an international $\mathrm{PhD}$ student, said she had to find 'her own solutions', because there were no solutions provided at the institutional level. Eleanor also had to find her own way, as she describes below. 
"In the times of critical need, when my daughter was really, really ill, then I had to take her to the hospital and I did not know how whom to call to. And she fainted. I didn't know if she is dead or alive and I called up my friends... Chevening friends, so somebody who was studying in the library, he said 'OK, I'm coming' and then we called the ambulance, we went to hospital, he stayed there throughout and came back in the next morning I had a presentation, I mean a group presentation so another friend, he offered to babysit because... so he stayed and I... and, and, when his classes were there, another person, another friend she came and she stayed till twelve o'clock in the afternoon and by that time I was back. That's how. So, see, the thing is: it wasn't the University, it was up to me to... to... to develop a circle or to, to... you know, to kind of create a support, support system for myself.» (Eleanor, full-time PG, single-mother, international student).

For these participants, family support is also important in their journey in higher education. Carrie described her husband's support as 'great' and believes that single mothers that manage to study and raise their children are 'saints'. She explains that when they first found out she was pregnant she was heartbroken and said she would not go back to university. Her husband, instead, said she was going, they could have a childminder, and that she would be fine. Even though she was sad about not having her parents and parents-in-law around, she appreciated her husband's support.

Maria mentioned she shares everything with her partner regarding housework and both have flexible shifts to take care of their one-year-old child, which is helpful. Jane is also extremely grateful for her husband to support her return to HE. She mentioned she was unhappy with her work and he encouraged her to find something she wanted to do, as seen in the quote below.

"[my husband] encouraged me to come back because he knew I was, I was, like, I still go there, I work part-time at Tesco [a British multinational groceries store] and I went for management and when I was sitting my test I was, like, 'I don't want this'! (...) The pay is good, but it's like really unsociable hours. I can work on the weekend again, I can work on during the middle of the night, I don't know where I'm gonna get posted, and that's not what I wanted. So, he was the one that was like 'what is that you want to do?', d'you know what I mean, is there something you really wanna do?' And he was like, re... like, I make alright money', he's a joiner, and he was, like, 'I make alright money', he's, like, 'why you don't go back [to university]?'.» (Jane, $3^{\text {rd }}$ year, Scottish Undergraduate Student).

It is interesting to note how fathers are praised by their partners. Carrie and Jane both seem to have immediately assumed full responsibility and then are subsequently surprised, relieved and highly praising of their partners who accept some care of their own children. It is a reminder how caring duties are still extremely gendered, and many mothers reproduce these roles' expectations in their own relationships.

Other members of the household might also be supportive, bridging a gap between caring and support. Irene, for instance, said her daughter was very supportive when she did not perform well in an assignment. She said she did not have enough time to study and was very disappointed with her grade, but her daughter tried to make her feel better. She also said her older son helps by proofreading her essays, which is a possibility of bridging the student and parent life. For Irene, childcare has an 
ambiguous impact on her HE experience: it is not only a tie that damp her student life but it also has a supportive role.

Alsop et al., (2008) discuss the marginal place of care in the WP agenda in the UK, pointing that the attention to mature students is not enough to embrace caring responsibilities. I agree with their ideas of the marginal place of care but extend them to analysing a single institution, that, in this case, collects little information on student-parents. Therefore, it cannot produce embracing policies and practices to welcome these mothers and support them when they need. Participants would benefit from having information on breastfeeding within campus or some flexibility of time to handle assessments, which is corroborated by Sallee and Cox (2019). In any case, participants of my research found more degree of support from individuals (members of staff and other students) than the reports from current literature, which suggests that connecting to supportive peers and lecturers is part of their attempt to navigate through university life. They still report, however, the need of more institutional support with policies and mechanisms that take into account their realities.

\subsection{Course and Career Choices}

The field of Sociology of Education has been discussing the extent of what appears to be individual HE course choices among high school students. Research has shown that gender, social class, religion, nationality, parents and friends are some of the features that help to define young people's approach to degrees and possible careers choices (Reay et al., 2005; Shah et al., 2010; Mirza and Meetoo, 2017; Williams et al., 2008). Mendick (2013), for example, explores gendered subject choice in Sciences, Technologies, Engineers and Mathematics (STEMs). Drawing from Bourdieu's (1979) critique on personal taste, Mendick's work is a reminder that even some of our most personal and individual features have powerful socially constructed influences.

Reports from my research participants also mentioned how their career choices are shaped by their context. They demonstrated they negotiate their dreams and desires due to their offspring and family demands. Carrie, who studies Archaeology and Celtic Studies, says she feels more attracted to the first subject, but she will probably stay only in the second programme. She points out the former as being a field that requires many hours of field and lab work, while the latter comprises more independent reading and studying, which is more flexible to her current life set up.
«In Archaeology, especially, you've got to put in, like, so many hours of practical experiences. And I just be... I can't, at the minute, I can't figure that out. So, this year... Researcher: Is it field work or lab?) Yes, field work or lab, do something in the lab, just something you got to get so many hours. And I'm just, like, I don't know how I'm going to fit that in'. So, I'm actually gonna have to basically drop... [That's w] hat I'm going to do.» (Carrie, undergraduate, $1^{\text {st }}$ year Scottish student).

Jane reported a related issue. She was studying Psychology and Social and Public Policy, but she dropped out of the former. She confessed that even though she enjoys public policy, her dream was to study Psychology and get Counselling once she finished university. However, her unpleasant experiences with the Psychology Department, that included unhelpful and unaccommodating staff and extra learning sessions on Fridays, led her to decide to withdraw from this programme of study. 
Meanwhile, Christina, an international student of Photography, mentioned that she cannot develop traditional photographs anymore because it deals with chemical products that could compromise her baby health as well as her own. Along with Irene, a European student, she also pointed out that their choice of a part-time programme was defined by their motherhood, both saying they would not be able to finish their course in one year. Even though she appreciates the possibility of studying parttime, Christina declared she would have preferred to study in a traditional classroom, where she would be able to connect more with other students and create a network of friends, instead of interacting in an online environment.

"Yeah, I only chose this course because I am a mother. Now I am a mother of two. And it is very
bard, you know, to balance... So, I said... I thought, part-time I can do from home, I can do
during the night, I can read, watch the videos in my own time, when he is at nursery or if anything
comes up... That was the reason. Otherwise, I could have chosen something else. [...] Because I
would not be able to stay in a university from 9 to 5 everyday, or not even if it's just three times
per week. I have many other responsibilities... with the children, I have to pick them up at school,
[...] take them to their activities...» (Christina, part-time distance PG student).

In sum, course and modes of study choices are restrained by the possibilities available to these students, and caring responsibilities hinder them to study what and how they want. It is valuable to observe how more flexible modes of study such as distance or part-time learning are important achievements of mature and other non-traditional students to ensure their participation in higher education setting. Christina suggests, however, that she would be happier if she could take part in a face-to-face course. As with other groups of non-traditional or underrepresented students, she had to adjust her course and career preferences due to by time availability and her other commitments. For these student-mothers gender roles of caring in their family shape strongly the possibilities available to them.

\subsection{Role Conflict, Student Wellbeing and Learning Difficulties}

Role theory has suggested that there are expected behaviours of people according to their social status and position in society. A university student, for example, is expected to spend time and resources studying while a mother is expected to spend time and resources with her family and/or child(ren). Classical sociology has compared these roles as performances on the stage of a theatre, where individuals act to form impressions of others and to behave as expected (Goffman, 1956). According to this theory, our daily activities, tasks and goals are shaped by these expected behaviours, and sometimes failure to perform them well produce consequences in the social, health or psychological spheres.

Meanwhile, role conflict happens when responsibilities of one role overlap with others. This occurs when extensive demands of time, resources or energy are required to meet the obligations of multiple roles that one person may have. Requirements from distinct activities affect individuals' health and wellbeing, which ultimately cause learning difficulties. Conflict of obligations from work and family spheres, for example, can cause depression, burnout, decreased job and life satisfaction and poor physical health (Andrade and Matias, 2017). On the other hand, research has shown that women report personal gratification when they feel that their roles are validated (Deutsch and Schmerz, 2011). 
Participants of my study revealed sleepless nights, tiredness and exhaustion as consequences of their life of mother and student. They also mentioned they felt guilty or miserable when they were unable to cope with university demands, which confirm findings from Ferree (1990). According to her, 'since housework supposedly flows out of her 'natural desire' to care for her family, a woman may feel guilty about every unmet 'need" (Ferree, 1990: 876). Eleanor, for instance, an international Postgraduate taught student, declared she feels miserable when she goes home to play with their kids instead of studying. The miserable or guilty feeling occurs when these mothers are not able to fully meet the expectations of what is perceived to be a 'good student' and a 'good mother'.

«when I am at home, I am a mum so I cannot... I cannot switch off and then, yes, 'OK, so I don't know you [the children], I am studying'. It never happens because they are around and they would like 'OK let's do this, let's play'. So, most of the time I end up feeling very miserable about myself.» (Eleanor, full-time PG, single-mother, international student).

Students' wellbeing at the university highly affects their learning. Participants reported that having to negotiate their time between their roles of mother and student obstructs their learning. Lack of time to study, because they are too tired, or not being able to study at home because they want to spend time with their children makes them have negative feelings. Therefore, it is unsurprising that having to carry out so many activities in their routine and not being able to fully cope with the students' commitments affect their perception of learning.

Some learning difficulties are hardly mensurable for students who are mothers. Jane, for instance, has commitments that most traditional students do not have: a house to run, children to take care of, a husband to spend time with and a job. Even though she believes it is a 'stupid thing', she wants her work and effort to be recognised as good as others, both compared to the ones with learning difficulties and to the traditional ones.

"It's such a stupid thing, but, see, when you're handling an essay and there is, like... in the bottom there, there is like a box to tick that says 'if you've got learning difficulties...', d'you know what I mean? Part of me was, like, I'd just love a box that says T've got two kids, a house to run, a husband and I got a part-time job, and I managed to write this essay!', like, 'mark mines just as good as!'» (Jane, $3^{\text {rd }}$ year, full-time Scottish Undergraduate student).

When the children face difficulties, their mothers must adapt to a new routine, which is challenging when the university has rigid timetables and deadlines. Participants widely mentioned that their ability to study and learn was compromised when their children fell ill. Some participants that agreed taking part in the study had to cancel with short or with no notice because their children had illness or were not feeling well. Christina, for example, who studies in a distance education programme, mentioned her children stopped going to the nursery when they were sick. As a result, she lost her time to study and, after coming back to university, it was challenging to catch up with the activities she missed.

Their university has guidelines for students who had unexpected difficulties that affected their examinations. The institution offers students to re-sit an exam or submit an assignment at a later date. There is a specific recommendation section on illness of a close relative, that usually counts as a 
reason good enough to affect someone's performance on an examination. Nevertheless, none of the participants that reported failing or performing below expected standards in an examination or assessment said they used this scheme, some of them were unaware of this policy. In addition, Carrie said she does not like telling her tutors or lecturers that she is a mother of a one-year-old daughter because she thinks it looks like an 'excuse' for her not doing her work well. Eleanor also mentioned she was not aware of the university student parents policy that, according to her, would grant special arrangements that will improve her performance and grades. In any case, the barrier to learning for Carrie and other participants is difficult to assess and measure, which makes it harder to justify objectively the need to receive a deadline extension or an exam re-sit for these participants.

This research supports findings from previous studies that lack of time is the most difficult barrier to learning (Bowl, 2003; Moss, 2004; Marandet and Wainwright, 2010). Moss (2004) found that women's personal time is usually the first thing to be sacrificed when they become mothers. Marandet and Wainwright (2010) indicated that student-parents in their research were in permanent state of exhaustion, expressing frustration and desolation. In other words, the expectation of a good performance in both the role of the student and the role of the mother affects their wellbeing, which directly impacts their learning experiences, academic achievement and possibilities for further study.

\section{Conclusion}

This study highlighted some of the experiences of these student-mothers that attend HE in Scotland, women who must negotiate their time and space between their multiple activities. It has found that the HE experiences of participants vary considerably, some of them feeling that the institution could do more to support them, others that receive this extra layer of support from family and friends. I also demonstrated that mothers had to make changes in their courses and careers' plan to accommodate their caring responsibilities and that some of them might feel upset or distress when they are not able to fulfil what is usually considered to be roles of 'good mothers' and 'good students'.

As indicated by the National Union of Students (2009), student-mothers' determination to succeed is constantly tested by inefficient policies, inaccessible institutional practices and misassumptions about the students' lives. On the other hand, if they have enough tools to support their journey through university life, which may include financial and emotional support and validation, they might navigate smoothly and even serve as an inspiration to young students.

There are issues that university policy or staff can easily tackle if they are able to listen to the voices of these women. Training for the student support staff that recognises these mothers aspire to more than a D3, for instance, is easily attainable by institutions. Furthermore, timetables published in advance will suit better students who have children to take care of (Marandet and Wainwright, 2010).

Moreover, this investigation looked upon an old and prestigious institution in Scotland, but non-traditional students are better represented in post-1992 institutions. Therefore, further research would benefit from an observation of distinct type of $\mathrm{HE}$ institutions. Another potentially interesting comparison would be with institutions in England, where students must pay tuition fees, which creates additional barriers to students from working class families. Finally, future research could explore the experiences of male students in HE who are fathers and their experiences of paternity, to find out which of their experiences overlap with student-mothers'. 
An inclusive approach to $\mathrm{HE}$ that ensures that these women can participate positively in university life with less barriers is needed. Mothers and other non-traditional students such as ethnic minorities, LGBT, foreigners or mature individuals need to find space in higher education where they can fulfil their desires, achieve their goals and do not feel isolated, neglected or overlooked. Their experience counts and their voice must be heard to guarantee a democratic and open space within universities and to promote wellbeing for all.

\section{Acknowledgements}

I thank all the mothers who decided to give some of their limited time to participate in this study. I also thank Catherine Wilkinson and Katherine Hubbard for providing useful comments to earlier versions of this draft.

\section{Bibliographical references}

Allen, T.ammy; Herst, David; Bruck, Carly and Sutton, Martha (2000): "Consequences Associated with Work-to-Family Conflict: A Review and Agenda for Future Research.” Journal of Occupational Health Psychology, 5, 278-308. DOI: https://doi.org/10.1037/1076-8998.5.2.278.

Alsop, Rachel; Gonzalez-Arnal, Stella and Kilkey, Majella (2008): “The Widening Participation Agenda: The Marginal Place of Care." Gender and Education, 20 (6): 623-637. DOI: https://doi. org/10.1080/09540250802215235.

Andrade, Cláudia and Matias, Marisa (2017): "Adding School to Work-Family Balance: The Role of Support for Portuguese Working Mothers Attending a Master's Degree.” Journal of Adult and Continuing Education, 23 (2): 143-161. DOI: https://doi.org/10.1177/1477971417721717.

Bourdieu, Pierre (1979). La Distinction. Critique Sociale du jugement. Paris: Les Éditions de Minuit.

Bowl, Marion (2003). Non-Traditional Entrants to Higher Education. Stoke on Trent: Trentham Books.

Braun, Virginia and Clarke, Victoria (2006): “Using Thematic Analysis in Psychology.” Qualitative Research in Psychology, 3, 77-101.

Brooks, Rachel (2012a): "Negotiating Time and Space for Study: Student-parents and Familial Relationships.” Sociology, 47 (3), 443-459. DOI: https://doi.org/10.1177/0038038512448565.

Brooks, Rachel (2012b): “Student-Parents and Higher Education: A Cross-National Comparison.” Journal of Educational Policy, 27 (3), 423-439. DOI: https://doi.org/10.1080/02680939.2011.613598.

Carers Trust Scotland (2020): "The Student Carer Experience in Scotland". Accessed $4^{\text {th }}$ February 2021. Retrieved from: https://carers.org/downloads/scotland-pdfs/the-student-carer-experience-in-scotland.pdf.

Cohen, Louis; Manion, Lawrence and Morrison, Keith (2018). Research Methods in Education. $8^{\text {th }}$ Edition. London: Routledge.

Creswell, John W. (2012). Educational Research: Planning, Conducting, and Evaluating Quantitative and Qualitative Research. London: Pearson. 
Deutsch, Nancy and Schmertz, Barbara (2011): “'Stating from Ground zero': Constraints and Experiences of Adult Women Returning to College." The Review of Higher Education, 34 (3): 477-504. DOI: https://doi.org/10.1353/rhe.2011.0002.

DeVault, Marjorie L. (1991). Feeding the Family: The Social Organization of Caring as Gendered Work. Chicago: The University of Chicago Press.

Ferree, Myra M. (1990): “Beyond Separate Spheres: Feminism and Family Research.” Journal of Marriage and the Family, 52, 866-884.

Goffman, Erving (1956). The Presentation of Self in Everyday Life. New York: Anchor Books.

Haugas, S. (2018): Pursuing Higher Education and Having Children: The Growing Need to Make it More Compatible. Eurostudent Intelligence Brief. Retrieved from: www.eurostudent.eu.

Leathwood, Carole and O'Connell, Paul (2003): “It's a Struggle': the Construction of the 'New Student' in Higher Education”. Journal of Education Policy, 18 (6), 597-615. DOI: https://doi.org/10.1080/026 8093032000145863.

Mack, Lindsay (2010): “The Philosophical Underpinnings of Educational Research.” Polyglossia, 19.

Marandet, Elodie and Wainwright, Emma (2010): “Invisible Experiences: Understanding the Choices and Needs of University Students with Dependent Children.” British Educational Research Journal, 36 (5), 787-805. DOI: https://doi.org/10.1080/01411920903165595.

Marshall, Catherine A. (2016): "Barriers to Accessing Higher Education" en Catherine A. Marshall, Sam J. Nolan and Douglas P. Newton (eds.): Widening Participation, Higher Education and Non-Traditional Students: Supporting Transitions through Foundation Programmes. London: Palgrave Macmillan.

Mendick, Heather (2013): “Choosing Subjects: Sociological Approaches to Young Women’s Subject Choices" en Rachel Brooks, Mark McCormack and Bhopal, Kalwant (eds.): Contemporary Debates in the Sociology of Education. London: Palgrave Macmillan.

Mirza, Heidi Safia and Meetoo, Veena (2017): "Empowering Muslim girls? Post-Feminism, Multiculturalism and the Production of the 'Model' Muslim Female Student in British Schools." British Journal of Sociology of Education, 39 (2), 227-241. DOI: https://doi.org/10.1080/01425692.2017.1406336.

Moreau, Marie-Pierre (2016): "Regulating the Student Body/ies: University Policies and Student parents." British Educational Research Journal, 42 (5): 906-925. DOI: https://doi.org/10.1002/berj.3234.

Moreau, Marie-Pierre and Kerner, Charlotte (2015): "Care in Academia: an Exploration of Student Parents' Experiences.” British Journal of Sociology of Education, 36 (2), 215-233. DOI: https://doi.org/10.1 080/01425692.2013.814533.

Moreton, Ian (2016): "Selecting Mature Students: A Toolkit for Admission Tutors" en Catherine A. Marshall, Sam J. Nolan and Douglas P. Newton (eds.): Widening Participation, Higher Education and Non-Traditional Students. London: Palgrave Macmillan. 
Moss, Dot (2004): "Creating Space for Learning: Conceptualizing Women and Higher Education Through Space and Time." Gender and Education, 16 (3), 283-302. DOI: https://doi.org/10.1080/09540250042 000251452.

National Union of Students (2019). "Meet the Parents: The Experience of Students with Children in Further and Higher Education". Accessed 26 $6^{\text {th }}$ June 2019. Retrieved from: https://www.nus.org.uk.

O’Shea, Sarah (2015): “'I Generally Say I am a Mum First... But I'm Studying at Uni': The Narratives of First-in-Family, Female Caregivers Transitioning into an Australian University". Journal of Diversity in Higher Education, 8 (4): 243-257. DOI: https://doi.org/10.1037/a0038996.

Reay, Diane; David, Miriam E. and Ball, Stephen (2005). Degrees of Choice: Social Class, Race and Gender in Higher Education. Staffordshire: Trentham Books Limited.

Sallee, Margaret W. and Cox, Rebecca D. (2019): "Thinking Beyond Childcare: Supporting Community College Student-Parents." American Journal of Education, 25, 621-645. DOI: https://doi. org/10.1086/704094.

Shah, Bindi; Dwyer, Claire and Modood, Tariq (2010): "Explaining Educational Achievement and Career Aspirations Among Young British Pakistanis: Mobilizing 'Ethnic Capital'?’' Sociology, 44 (6): 11091127. DOI: https://doi.org/10.1177/0038038510381606.

Sweet, Stephen and Moen, Phyllis (2007): "Integrating Educational Careers in Work and Family." Community, Work and Family, 10 (2), 231-250. DOI: https://doi.org/10.1080/13668800701270166.

Williams, Katya; Jamieson, Fiona and Hollingworth, Sumi (2008): “He Was a Bit of a Delicate Thing': White Middle-Class Boys, Gender, School Choice and Parental Anxiety." Gender and Education, 20 (4), 399-408. DOI: https://doi.org/10.1080/09540250802190230.

Witkowsky, Patricia; Mendez, Sylvia; Ogunbowo, Oluwafolakemi; Clayton, Grant and Hernandez, Nancy (2016): "Nontraditional Student Perceptions of Collegiate Inclusion." The Journal of Continuing Higher Education, 64(1), 30-41. DOI: https://doi.org/10.1080/07377363.2016.1130581.

\section{Biographical notes}

Thiago Bogossian is a PhD candidate in Sociology of Education at the University of Surrey. He has a master's degree in Adult Education for Social Change from an international consortium between the University of Glasgow, University of Malta Malta, Tallinn University and Open University of Cyprus and a bachelor's degree in Geography from Fluminense Federal University. Thiago is a Teaching Assistant at the Department of Sociology at the University of Surrey and Assistant with the Journal of Ethnic and Racial Studies. 